\title{
Studies on Genetic Parameters for Diversified Uses in Sugarcane (Saccharum spp.)
}

\author{
M. Shanthi Priya ${ }^{*}$, K.H.P. Reddy, M. Hemanth Kumar, \\ V. Rajarajeswari and G. Mohan Naidu
}

Department of Genetics and Plant Breeding, Agricultural College, Mahanandi, Andhra Pradesh - 518 501, India

*Corresponding author

\section{A B S T R A C T}

\section{Keywords}

Sugarcane (Saccharum spp.), Fibre, Jaggery

Article Info

Accepted:

22 July 2018

Available Online:

10 August 2018

\begin{abstract}
Seventy three genotypes were evaluated for diversified uses viz., biomass per cane, fibre yield, theoretical yield of alcohol, commercial cane sugar (CCS) yield and cane yield in second clonal stage. The characters viz., shoot population at 240 DAP, stalk length, number of millable canes, fibre content, brix, sucrose, CCS per cent, pol per cent cane, total sugars per cent, biomass per cane, fibre yield, CCS yield, theoretical yield of alcohol and cane yield showed high heritability coupled with high genetic advance as per cent of mean indicating that these characters were under the influence of additive gene effects and selection would be effective for the improvement of these characters.
\end{abstract}

\section{Introduction}

Sugarcane is an important cash crop of India. In India it is grown in sub-tropical and tropical climatic regions. Sugarcane crop serves as the major source for a variety of products such as sugar, jaggery, molasses, bagasse and filter cake out of which sugar and jaggery are meant for daily use as consumable products while other byproducts have industrial significance. It is realized that sugar production alone will not be able to make the industry profitable and under such circumstances diversification is a necessary consequence for the successful growth of industry. Sugarcane, an important bio energy crop belongs to the category of $\mathrm{C} 4$ plants which converts the solar energy effectively into high quality and low cost raw materials for sugar and ethanol (Bruce et al., 2005). Molasses and bagasse are the byproducts of sugar industry which form the feedstock for ethanol production and cogeneration respectively. Generally the main objective of sugarcane breeding is to develop varieties capable of producing high sugar yields per unit land area. The recent awareness on the advantages of using green fuel for generation of power and use of gasohol to reduce automobile emission have resulted in setting up of a number of cogeneration plants and distilleries in various sugar mills. To achieve these goals of increased sugar, alcohol and cogeneration, sugar industries need special varieties to meet their specific 
requirement of raw materials. Hence, breeding programmes must integrate new traits such as high fiber, high biomass and high total sugars in addition to cane yield and juice quality.

Breeding for higher yield and quality traits requires basic information on the extent of genetic variation in a population and its response to selection. Understanding various genetic parameters that govern a population under improvement is essential for proper planning and direction of plant breeding program. The success of such program will depend upon largely on the extent of genetic variability available in the base population and heritability of the characters under improvement. Therefore, a clear understanding of genetic parameters is of paramount importance in the development of a breeding strategy (Singh et al., 2002). The information on the nature and magnitude of variability present in the genetic material is of prime importance for a breeder to initiate any effective selection programme. Genotypic and phenotypic coefficients of variation along with heritability as well as genetic advance are very essential to improve any trait of sugarcane because this would help in knowing whether the desired objective can be achieved from the material or not (Tyagi and Singh, 1998). Hence, in the present study the nature and extent of genetic variability, heritability and genetic advance for twenty seven characters were estimated in second clonal stage.

\section{Materials and Methods}

The present investigation was carried out at Agricultural Research Station, Perumallapalle (Acharya N.G. Ranga Agricultural University), situated in the Southern Agroclimatic Zone of Andhra Pradesh, India. The experimental material consisted of 77 genotypes including four checks viz., Co 6907, Co 7219, 2003 V46 and Co 86032. The seventy seven genotypes were planted in a randomized block design with two replications during April, 2011. Each entry was planted in 2 rows of $5 \mathrm{~m}$ length spaced at a distance of $80 \mathrm{~cm}$ between rows with 4 three budded setts per meter as seed rate. Fertilizers were applied at recommended dose of 224:112:112 kg ha $\mathrm{N}, \mathrm{P}_{2} \mathrm{O}_{5}$ and $\mathrm{K}_{2} \mathrm{O}$ The recommended dose of $\mathrm{P}_{2} \mathrm{O}_{5}$ and $\mathrm{K}_{2} \mathrm{O}$ were applied as basal and nitrogen was applied in two equal split doses at 45 and 90 days after planting. Cultural practices like weeding, irrigation, earthing up and propping were followed to maintain good crop growth.

Phenotypic and genotypic coefficients of variation were computed using the formulae given by Burton (1952). The range of variation was categorized according to Sivasubramanian and Madhavamenon (1973). Heritability in broad sense was estimated as suggested by Lush (1940). Genetic advance as per cent of general mean was computed by using the formula given by Johnson et al., 1955.

Data were recorded on seventy seven genotypes including four checks for twenty seven characters viz., tiller number at 120 DAP, shoot population at 180 and 240 DAP, number of green leaves at 90, 120, 240 DAP and at maturity, number of internodes, internode length, stalk length, stalk diameter, stalk volume, NMC per plot at harvest, single cane weight, fibre content, brix per cent, sucrose per cent, CCS per cent, juice purity per cent, pol per cent cane, juice extraction per cent, total sugars per cent, biomass per cane, fibre yield, CCS yield, theoretical yield of alcohol and cane yield.

\section{Results and Discussion}

Mean, Range, GCV, PCV, heritability (broad sense) and genetic advance as percentage of mean for twenty seven characters in seventy seven genotypes of sugarcane are presented in 
Table 1. The GCV and PCV values were high for the traits viz., number of leaves at maturity, stalk volume, total sugars, biomass per cane, fibre yield, commercial cane sugar yield, theoretical yield of alcohol and cane yield indicating that the variability observed in the seventy seven genotypes was high.

Moderate variability was observed for the traits viz., number of tillers at 120 DAP, shoot population at 180 and 240 DAP, number of leaves at 90 and 240 DAP, number of internodes per cane, internode length, stalk length, number of millable canes, single cane weight, fibre content, brix per cent, sucrose per cent, CCS per cent and pol per cent cane. The low GCV values for number of green leaves at 120 DAP, stalk diameter, juice purity per cent and juice extraction per cent indicated that the variability was low for these traits in the seventy seven genotypes. Critical analysis of the results pertaining to genetic parameters indicated that the characters viz., shoot population at $240 \mathrm{DAP}$, stalk length, number of millable canes, fibre content, brix, sucrose, CCS per cent, pol per cent cane, total sugars, biomass per cane, fibre yield, CCS yield, theoretical yield of alcohol and cane yield showed high heritability coupled with high genetic advance as per cent of mean indicating that these characters are controlled by additive gene effects and selection would be effective for these characters.

\begin{tabular}{|c|c|c|c|c|c|c|c|c|}
\hline \multirow[t]{2}{*}{ S. No. } & \multirow[t]{2}{*}{ Character } & \multicolumn{2}{|c|}{ Range } & \multirow[t]{2}{*}{ Mean } & \multirow[t]{2}{*}{ GCV } & \multirow[t]{2}{*}{ PCV } & \multirow[t]{2}{*}{$\mathbf{h}^{2}$} & \multirow{2}{*}{$\begin{array}{l}\text { GA }(\%) \\
\text { of mean }\end{array}$} \\
\hline & & Min & Max & & & & & \\
\hline 1 & Tillers at 120 DAP & 71.00 & 175.00 & 117.00 & 10.05 & 20.64 & 23.71 & 10.08 \\
\hline 2 & Shoot population at $180 \mathrm{DAP}$ & 52.00 & 130.00 & 90.00 & 12.84 & 19.96 & 41.16 & 16.68 \\
\hline 3 & Shoot population at $240 \mathrm{DAP}$ & 53.00 & 155.00 & 95.00 & 15.55 & 16.28 & 91.13 & 30.57 \\
\hline 4 & No. of green leaves at $90 \mathrm{DAP}$ & 9.50 & 27.00 & 15.72 & 17.28 & 29.92 & 33.36 & 20.56 \\
\hline 5 & No. of green leaves at 120 DAP & 9.50 & 24.50 & 16.99 & 9.12 & 24.76 & 13.58 & 6.93 \\
\hline 6 & No. of green leaves at $240 \mathrm{DAP}$ & 7.00 & 15.00 & 9.72 & 10.34 & 22.54 & 21.03 & 9.77 \\
\hline 7 & No. of green leaves at maturity & 5.67 & 18.83 & 12.62 & 21.66 & 28.10 & 59.13 & 34.22 \\
\hline 8 & No. of internodes per cane & 14.33 & 29.00 & 21.65 & 12.21 & 18.79 & 42.24 & 16.35 \\
\hline 9 & Internode length $(\mathrm{cm})$ & 8.62 & 17.71 & 12.70 & 11.94 & 19.15 & 38.84 & 15.32 \\
\hline 10 & Stalk length $(\mathrm{cm})$ & 185.00 & 368.00 & 267.81 & 12.77 & 13.11 & 94.82 & 25.61 \\
\hline 11 & Stalk diameter $(\mathrm{cm})$ & 1.90 & 3.40 & 2.53 & 8.40 & 13.54 & 38.50 & 10.74 \\
\hline 12 & Stalk volume $\left(\mathrm{cm}^{3}\right)$ & 685.27 & 2556.91 & 1362.45 & 20.26 & 29.36 & 47.62 & 28.80 \\
\hline 13 & NMC at harvest & 40.00 & 118.00 & 82.96 & 17.28 & 20.35 & 72.04 & 30.21 \\
\hline 14 & Single cane weight $(\mathrm{kg})$ & 0.68 & 1.59 & 1.07 & 15.45 & 21.81 & 50.18 & 22.55 \\
\hline 15 & Fibre content $(\%)$ & 9.44 & 21.44 & 14.55 & 19.37 & 19.48 & 98.81 & 39.66 \\
\hline 16 & Brix $(\%)$ & 9.59 & 20.81 & 17.13 & 13.51 & 13.96 & 93.78 & 26.96 \\
\hline 17 & Sucrose $(\%)$ & 8.27 & 20.22 & 15.61 & 16.21 & 16.33 & 98.57 & 33.16 \\
\hline 18 & CCS percentage $(\%)$ & 7.18 & 14.61 & 11.01 & 16.26 & 16.36 & 98.78 & 33.30 \\
\hline 19 & Juice purity (\%) & 80.63 & 98.47 & 90.85 & 4.19 & 4.66 & 80.79 & 7.76 \\
\hline 20 & Pol \% cane $(\%)$ & 6.73 & 16.98 & 13.33 & 16.02 & 16.14 & 98.00 & 32.74 \\
\hline 21 & Juice extraction (\%) & 54.23 & 73.61 & 63.47 & 7.45 & 7.53 & 96.00 & 15.00 \\
\hline 22 & Total sugars (\%) & 11.46 & 29.25 & 20.38 & 20.20 & 21.08 & 91.82 & 39.88 \\
\hline 23 & Biomass per cane $(\mathrm{kg})$ & 1.00 & 2.85 & 1.56 & 20.31 & 21.27 & 91.18 & 39.94 \\
\hline 24 & Fibre yield $\left(\mathrm{t} \mathrm{ha}^{-1}\right)$ & 7.25 & 30.06 & 15.76 & 28.57 & 29.80 & 91.92 & 56.43 \\
\hline 25 & CCS yield $\left(\mathrm{t} \mathrm{ha}^{-1}\right)$ & 5.76 & 20.73 & 12.00 & 28.34 & 29.51 & 92.00 & 56.09 \\
\hline 26 & Theoretical yield of alcohol (g/100ml) & 1.79 & 14.67 & 9.29 & 26.06 & 27.17 & 91.96 & 51.47 \\
\hline 27 & Cane yield $\left(\mathrm{t} \mathrm{ha}^{-1}\right)$ & 54.06 & 205.49 & 109.84 & 26.76 & 28.00 & 91.32 & 52.67 \\
\hline
\end{tabular}

These results are in agreement with the findings of Singh and Singh (1994) for brix per cent; Das et al., (1996), Ghosh and Singh (1996) for number of millable canes and cane yield; Singh et al., (1996) for commercial cane sugar, and cane yield; Ravishankar et al., (2003) for cane yield, commercial cane sugar yield, CCS per cent and juice brix; Berding 
and Pendrigh (2009) for brix, commercial cane sugar, dry matter and fibre content; Krishna et al., (2011) for sucrose per cent and CCS per cent; Mancini et al., (2012) for pol per cent cane.

The existence of sufficiently large genetic variability and less influence of environment on these traits facilitates effective phenotypic selection.

Number of green leaves at 90 DAP and at maturity, stalk volume and single cane weight exhibited low to moderate heritability coupled with high genetic advance as per cent of mean indicating that these traits are governed by additive gene effects, hence selection may be effective for these characters but low or moderate heritability might be due to high environmental effects.

Similar results of importance of additive gene action for number of millable canes, single cane weight, cane yield, stalk volume (Charumathi, 2011), sugar yield (Sabitha and Rao, 2008), shoot population (Sabitha, 2007), stalk length (Navneeth et al., 2010) were also reported in sugarcane. Whereas non additive gene action was reported for CCS per cent (Sabitha, 2007), shoot population (Deep et al., 2004), number of millable canes (Kadian et al., 1997), single cane weight and stalk length (Tyagi and Singh, 2000).

Juice purity and juice extraction per cent showed high heritability coupled with low genetic advance as per cent of mean which indicated that these traits were governed by non-additive gene action and hence selection for these characters may not be rewarding. These results are in conformity with the findings of Tyagi and Singh (2000), Sabitha and Rao (2008), Charumathi (2011), Ahmed and Obeid (2012) for juice purity per cent.

The traits viz., shoot population at 180 , number of green leaves at 120, 240 DAP, tiller number at 120 DAP, internode number, internode length and shoot diameter registered low to moderate heritability coupled with low to moderate genetic advance as per cent of mean indicating that these traits are highly influenced by environmental effects and selection for these characters would be ineffective.

\section{References}

Ahmed, A.O and Obeid, A. 2012. Investigation on variability, broad sensed heritability and genetic advance in sugarcane (Saccharum spp). International Journal of Agricultural Science. 2 (9): 839-844.

Berding, N and Pendrigh, R.S. 2009. Breeding implications of diversifying end uses of sugarcane. International Sugar Journal. 111 (1331).

Bruce, S., Dien, Nagle, N., Vijay Singh., Moreau, R.A., Tucker, M.P., Nichols, N.N., Johnston, D.B., Cotla, M.A., Hicks, K.B., Nguyen, Q and Bothast, R.J. 2005. Review of process for producing corn fiber oil and ethanol from "Quick fiber". International Sugar Journal. 107(1275): 187-190.

Burton, G.W. 1952. Quantitative inheritance in grasses. Proceedings of $6^{\text {th }}$ International Grassland Congress.1: 227-283.

Charumathi, M. 2011. Studies on selection indices in sugarcane (Saccharum officinarum L.). PhD Thesis submitted to the Acharya N. G. Ranga Agricultural University Hyderabad.

Das, P.K., Jena, B.C., Nayak, $\mathrm{N}$ and Parida, A.K. 1996. Correlation and path analysis of cane yield in sugarcane. Cooperative Sugar. 27(7): 509-512.

Deep, G., Mehla, A. S., Punia M. S and Kadian, S. P. 2004. Studies on Variability, Heritability and Genetic gain for yield, its components and quality traits in sugarcane (Saccharum complex). Indian Sugar: 733-737.

Ghosh, J and Singh, J.R.P. 1996. Variability in early maturing clones of sugarcane 
(Saccharum spp). Cooperative Sugar. 27 (5): 341-344.

Johnson, H.W., Robinson, H.F and Comstock, R.E. 1955. Estimates of genetic and environmental variability in soybean. Agronomy Journal, 47: 314-318.

Kadian, S. P., Singh, J. V., Sabharwal, P. S and Yadav, J. S. 1997. Variability, heritability and genetic advance for yield and yield contributing characters in sugarcane. Agricultural Science Digest, Karnal. 17(1):51-53.

Krishna, U.S., Hemanth Kumar, M., Mohan Reddy, D and Naga Madhuri, K.V. 2011. Study on genetic variability, heritability and genetic advance in plant and ratoon crops of sugarcane. Geobios. 38 (4): 221 224.

Lush, J.L. 1940. Intra-sire correlation and regression of offspring in rams as a method of estimating heritability of characters. Proccedings of American Society, Animal Product. 33: 292-301.

Mancini, M.C., Leite, D.C., Perecin, D., Bidoia, M.A.P., Xavier, M.A., Landell, M.G.A and Pinto, L.R. 2012. Characterization of the genetic variability of a sugarcane commercial cross through yield components and quality parameters. Sugar Tech. 14 (2): 119-125.

Navneeth Kumar, Tejbir Singh and Vinit Kumar. 2010. A study on genetic parameters, repeatability and predictability in plant and ratoon crops of sugarcane (Saccharum officinarum L). Indian Sugar. 60(2) 23-27.

Ravishankar, C. R, Ramappa, H. K, Prakash, P and Puttarama Naik. 2003. Genetic variability and correlation studies in sugarcane. Environment and Ecology. 21 (4): 951-954

Sabitha, N and Rao, P. K. 2008. Promising high yielding and sucrose rich early maturing sugarcane clones for Andhra Pradesh. SISSTA Journal 39th Annual Convention of SISSTA. 11-13.

Sabitha, N. 2007. Genetic parameters and selection indices in sugarcane (Saccharum officinarum L.). M.Sc (Ag.) Thesis submitted to the Acharya N. G. Ranga Agricultural University Hyderabad.

Singh, A., Bhatnagar P.K., Khan A.Q and Shrotria P.K. 2002. Variability and heritability for cane yield, its components and quality characters in sugarcane (Saccharum spp complex). Indian Sugar Journal. 53 (4): 717-719.

Singh, A.P., Chatterjee, A and Nema, G.K. 1996. Genetic variability in sugarcane (Saccharum sp. Complex.). Crop Research, Hisar. 12(2): 162-164.

Singh, R.K and Singh, S. 1994. Early evaluation of crosses for varietal improvement in sugarcane. Sugarcane 3: 17-21.

Sivasubramanian, V and Madhavamenon, P. 1973. Path analysis for yield and yield components of rice. Madras Agricultural Journal. 60: 1217-1221.

Tyagi, S.D and Singh, D.N. 1998. Studies on genetic variability for stalk characters in sugarcane. Indian Sugar. XL VIII: 259262.

Tyagi, S.D and Singh, D.N. 2000. Correlation and heritability studies in sugarcane. Indian Sugar 50(5): 303-308.

\section{How to cite this article:}

Shanthi Priya, M., K.H.P. Reddy, M. Hemanth Kumar, V. Rajarajeswari and Mohan Naidu, G. 2018. Studies on Genetic Parameters for Diversified Uses in Sugarcane (Saccharum spp.). Int.J.Curr.Microbiol.App.Sci. 7(08): 4138-4142. doi: https://doi.org/10.20546/ijcmas.2018.708.431 